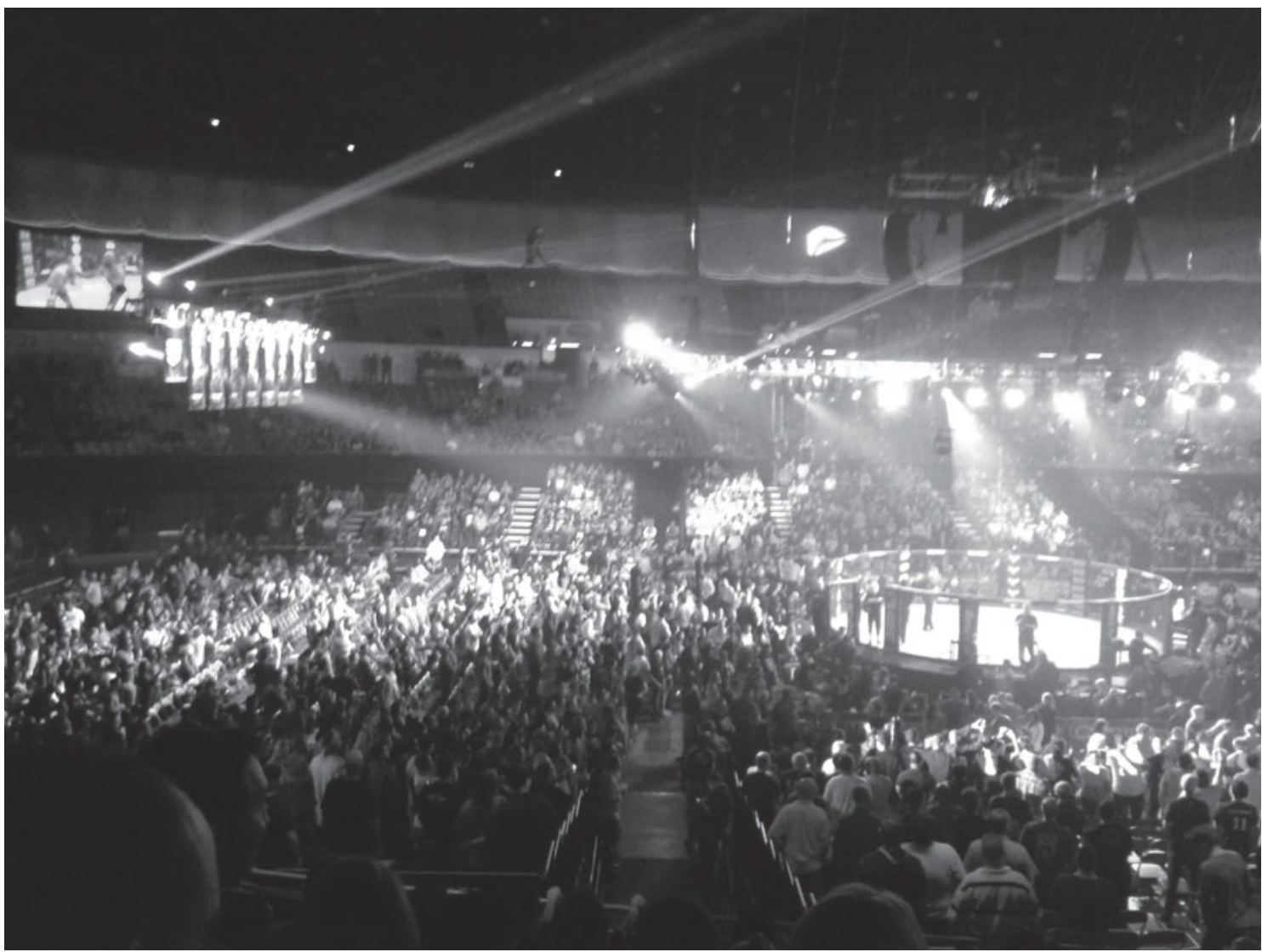

\title{
Mixed Martial Arts og det totale engagement
}

- om amerikanske eliteudøveres traening og praksisfallesskab 


\section{INDLEDNING}

Set udefra kan Mixed Martial Arts (MMA) opleves som en brutal, blodig og regelløs slåskamp, der på ingen måde kan anses som en sport. Men omvendt så er MMA på en hel del områder ikke anderledes end megen anden kampsport, eksempelvis boksning og taekwondo, hvor udøverne i kontrollerede situationer konkurrerer $\mathrm{i}$ at anvende kampteknikker, som kan forvolde skade på modstanderen (Woodward, 2009). I lighed med anden kampsport kræver det en stor træningsindsats og et stærkt engagement før udøverne går ind i 'buret ${ }^{\text {'1 }}$ for at vinde kampen.
MMA eliten finder man i USA, og de amerikanske træningsmiljøer fungerer derfor på mange måder som et ideal af betydning for, hvordan træningspraksissen udfolder sig i det spirende MMA miljø i Danmark. ${ }^{2}$ Der er dog skrevet meget lidt og analyseret endnu mindre om, hvad det er for en træningspraksis, der er forbundet med MMA udøvelsen.

I nyere dansk idrætsforskning om talentudvikling er det træningsfællesskab, som udøverne indgår i blevet beskrevet som et praksisfællesskab, der på forskellig vis er organiseret i forhold til udøvernes familie-, venne- og ud-

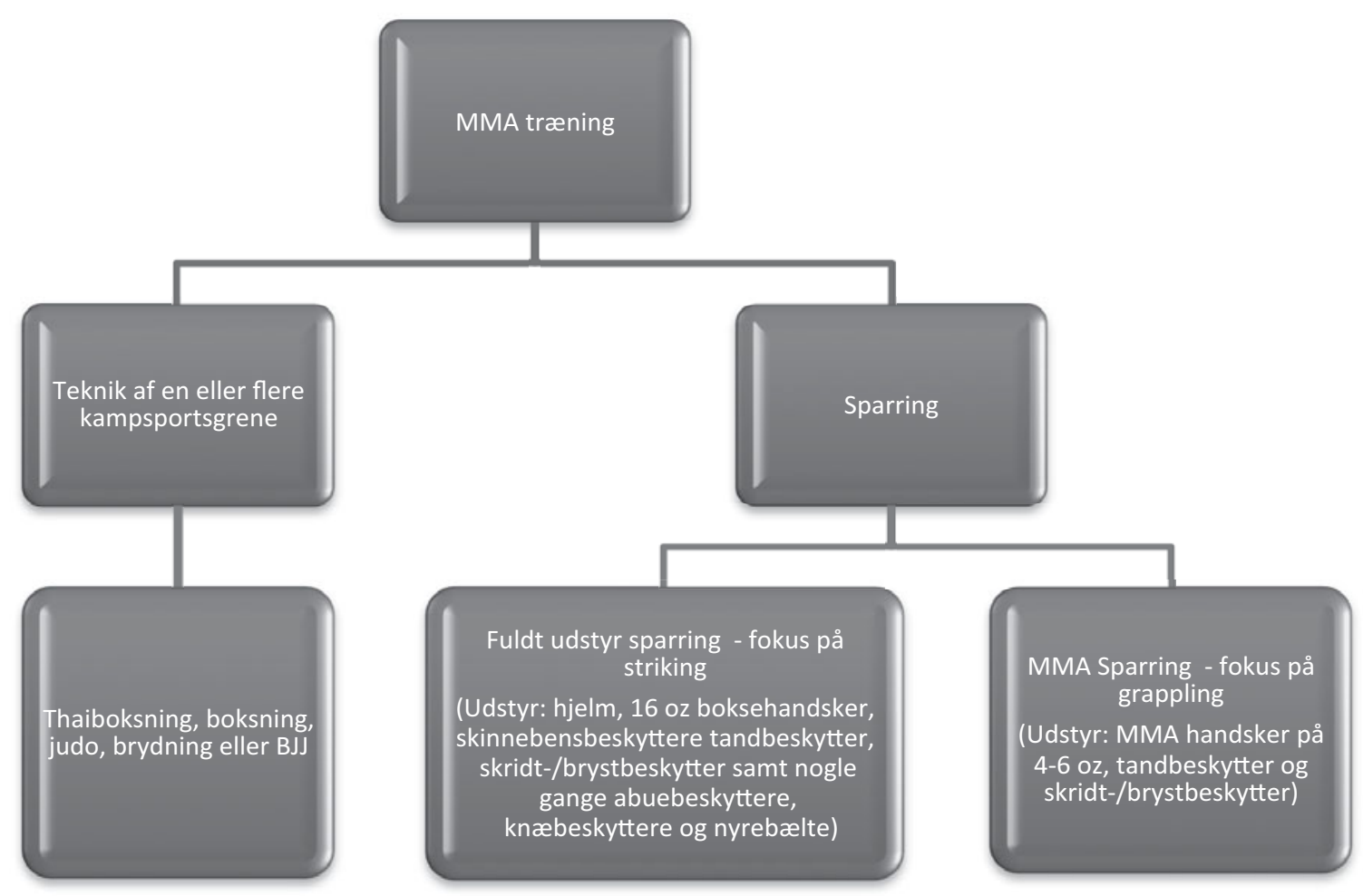

Figur 1: Figuren illustrerer, hvordan MMA udøverne træner MMA. 

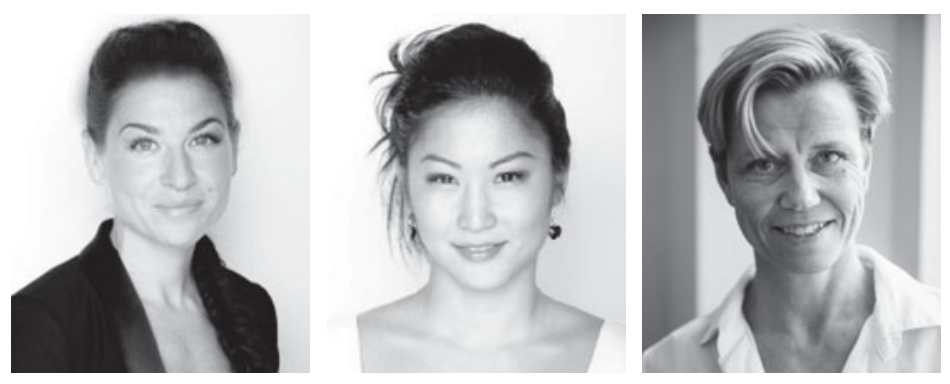

dannelsesliv (se eksempelvis Henriksen, 2010 og Larsen, 2013). Set i den sammenhæng udgør MMA en interessant case i og med, at det træningsfællesskab, som MMA udøverne må forventes at være en del af, er placeret uden for den accepterede elitesport og derfor udfolder sig på andre betingelser. Det er formålet med denne artikel, at beskrive det amerikanske MMA træningsfællesskab og perspektivere dette fællesskab til den måde træningsfællesskabet organiseres på i dansk eliteidræt. Artiklen er baseret på i alt fem måneders etnografisk feltarbejde af artiklens to første forfattere i MMA 'hovedstæderne' Las Vegas og Los Angeles.

\section{KORT OM MMA}

MMA har sine rødder i Vale Tudo fra Brasilien, som betyder [kamp] uden regler. Vale Tudo blev promoveret som en konkurrence, der skulle afgøre hvilken kampkunst, der var mest effektiv i ubevæbnede kampsituationer. I slutningen af 1990'erne flyttedes fokus fra de individuelle kampsportsgrene inden for MMA til de individuelle udøvere. Fuldkontaktsporten MMA fremstår i dag som en blanding af thaiboksning, boksning, judo, brydning og brasiliansk ju jitsu (BJJ) og for at være blandt de bedste udøvere i MMA i dag er det nødvendigt at kunne mestre flere forskellige elementer af disse kampformer (Spencer, 2009). Overordnet set inddeler man
MMA færdighederne i forhold til to kategorier: Striking (spark og slag med forskellige kropsdele) og grappling, hvor deltagerne forsøger at få hinanden i gulvet (via fodfejning, kast og andre former for nedtagning) og fortsætter i gulvkamp (med strangulering, låse, clinching og pinning) (Rooney, 2008, s.6; Spencer, 2009). Tidligere var MMA den kampsport, der havde færrest restriktioner. Det vil sige, at næsten alle slag og spark var tilladt både stående og på gulvet. Men efter MMA har været igennem en gennemgribende forandring (Spencer, 2009) er der i dag 31 nedskrevne regler for, hvad udøverne ikke må. Sammenlignet med en af verdens største bokseorganisationer World Boxing Council, er der omtrent samme antal regler i forhold til, hvad der ikke er tilladt i kamp.

\section{TEORI}

Med afsæt $\mathrm{i}$ analyser af forskellige mesterlæreforhold har læringsteoretikeren Étienne Wenger (2008) udviklet en teori, der beskriver praksisfallesskabets betydning for deltagernes socialisering og identitetsforståelse. I Wengers beskrivelser forstås deltageren og deltagelse som noget, der på en gang er personligt (inkluderer et kropslig og følelsesmæssige engagement) og socialt, dvs. er betinget af en form for gensidig anerkendelse $\mathrm{i}$ forhold til den aktuelle praksis. Wengers teoretiske beskrivelser åbner således for en nærmere analyse af dynamikken mellem 
deltagernes socialisering, læring og tilhørsforhold.

Wenger har i lighed med eksempelvis Pierre Bourdieu såvel som Erving Goffman, fremhævet at udførelsen af forskellige praktiske færdigheder også altid er en social praksis. Wengers beskrivelse af praksisfællesskabet giver dog et andet og mere konkret forankret afsæt for at analysere, hvorledes mening og forståelse af en praksis både inkluderer en tavs kropslig viden, sprog, redskaber, billeder samt veldefinerede roller, for de der er en del af praksis (2008, s.62). Ved at tage del i den aktuelle praksis både tilegner, påvirker og manifesterer deltageren således grundlæggende antagelser, uskrevne regler såvel som implicitte relationer for fællesskabet, og hvad det vil sige at være udøver indenfor det aktuelle træningsfællesskab. Deltagelse i et praksisfællesskab er i Wengers terminologi karakteriseret ved tre dimensioner: gensidigt engagement, falles virksomhed og falles repertoire (Ibid., s. 89-90). Den enkelte deltagers unikke placering, set i forhold til det gensidige engagement, er grundlæggende for den enkeltes deltagers oplevelse af identitet. Det er ligeledes via det gensidige engagement, at interpersonelle relationer udvikles. Den fælles virksomhed inkluderer en kollektiv forhandlingsproces, et fælles genkendeligt mål og en gensidig ansvarlighed blandt deltagerne og er betinget af, at deltagerne deler en form for fælles repertoire. Det fælles repertoire omfatter eksempelvis bestemte måder at gøre noget på, historier, symboler og begreber, som fællesskabet har produceret eller taget til sig (Ibid., s.100-101).

Som det fremgår af de næstfølgende beskrivelser blev det undervejs i feltarbejdet meget klart at familie og nære venner spiller en stor rolle for MMA udøvernes måde at indrette deres træning på - specielt i forbindelse med deres forberedelser op til kamp. I sin samfundsorienterede analyse berører den britiske sociolog Anthony Giddens' begrebet privatsfoere - dvs. familie og nære venners betydning for individets selvforståelse (1990). De relationer, der hører privatsfæren til, er ikke betinget af at den fælles virksomhed rettet mod en form for produktion. Tillidsforhold er i stedet funderet $i$ et gensidigt følelsesmæssigt engagement (Giddens, 1990, s.114-121). Det betyder også, at der indenfor privatsfæren er en tendens til at tillidsforholdet og gensidigheden i relationerne meget nemt tages for givet (Ibid., s.118-121). Som Wenger selv gør opmærksom på, er det ikke alle interpersonelle relationer, der er funderet i praksisfællesskaber (Ibid., s.93-95). Giddens beskrivelse af privatsfæren kan forstås som noget, der ligger ved siden af eller rækker ud over et praksisfællesskab.

Som det implicit fremgår af indledningen, er MMA kampen ikke blot en test af færdigheder og mod, men også en iscenesættelse af en bestemt kampforståelse. Den praksis, der er en del af MMA udøvernes repertoire kan dermed oplagt forstås i forhold til Goffmans beskrivelser af henholdsvis 'frontstage' versus 'backstage' (Goffman, 1990, s.37, 114-115, 131). Goffman er specielt interesseret $i$ at analysere og beskrive den sociale regulering af menneskelige adfærd (Jacobsen, 2013, s.151). Det er i den sammenhæng vigtigt at forstå at 'frontstage' og 'backstage' aktiviteter er tæt forbundne - den ene betinger den anden. 'Frontstage' vil for MMA således handle om de dele af aktiviteterne, der fungerer som en kollektiv repræsentation (Goffman, 1990, s.37), mens 'backstage' vil være forbundet med områder og sammenhænge, hvor udøverne ikke behøver at præsentere den front, der udgør en del af den kollektive repræsentation (Ibid., s.115-116). 


\section{METODE}

Det etnografiske feltarbejdet udførtes som flerstedet feltarbejde (Brinkmann og Tanggaard, 2010, s.1, 57) og forløb over to gange af hver 1011 uger. Første periode (foråret 2013) bestod af observation og relativt strukturerede interview med i alt 37 MMA udøvere (35 mænd og 2 kvinder) fra seks MMA klubber. En kombination af kvantitative opgørelser og kvalitativ analyse ${ }^{3}$ har dannet baggrund for det efterfølgende feltarbejdet (efteråret 2013) i syv MMA klubber med speciel fokus på det daglige træningsliv for 12 udøvere (10 mænd og 2 kvinder), der hører til blandt verdenseliten. Første feltarbejdsperiode har således dannet grundlag for en mere fokuseret feltarbejdsperiode. Deltagerobservationerne og de uformelle interviews, der fandt sted både i og uden for MMA klubberne, har fungeret kontekstualiserende for de 12 formelle interviews. ${ }^{4}$ Det vil sige, at den måde udøverne organiserer deres liv i forhold til MMA, og de ordvalg og værdier udøverne anvender, når de taler om deres træning, har dannet grundlag for udformningen af interviewguiden, og den måde forskellige forhold har været bragt ind undervejs $\mathrm{i}$ interviewet (Hammersley og Atkinson, 2007, s. 3-4, $8,113-117,161)$. Den videre analyse har primært haft fokus på de transskriberede 12 interviews, som er blevet kodet $i$ forhold til overordnede temaer ${ }^{5}$ bestemt af analysen af første feltarbejde (Brinkmann og Tanggaard, 2010, s.55-56, 71).

\section{KARAKTERISTIKA AF MMA UDøVERNE}

De 37 udøvere som blev interviewet i første del af feltarbejdet var i alderen 21-48 år og havde dyrket MMA mellem 6 måneder og 12 år. De havde i gennemsnittet haft 12 MMA kampe i løbet af deres karriere, og knap halvdelen (14) af udøverne kæmpede for UFC og Bellator de stør-

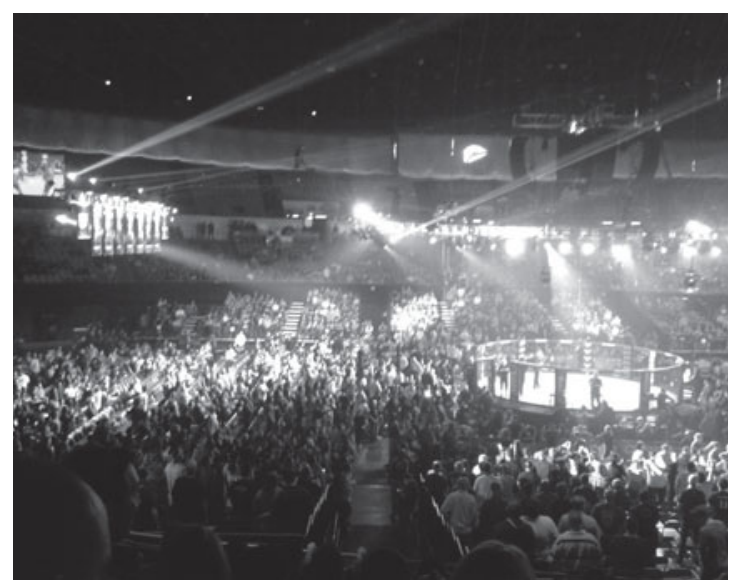

Buret også kaldet 'The Octagon'. Foto: Mariam Rosenwanger.

ste MMA organisationer i verden. 16 udøvere havde en udannelse (college: 8 , universitetsuddannelse: 7, erhvervsuddannelse: 1) og 21 havde ingen eller ikke nogen videre uddannelse udover high school. De fleste arbejdede ved siden af deres træning og kampe, for at økonomien kunne hænge sammen.

De 12 udøvere som vi fulgte i feltarbejdets anden del lever af MMA, hvilket betyder at deres indkomst udelukkende kommer fra MMA relaterede aktiviteter; via forskellige kombinationer af betaling for kampene, diverse sponsor og eventrelaterede sammenhænge, og trænerjobs. På det tidspunkt interviewene fandt sted tjente de 12 udøvere mellem $\$ 10.000$ til \$1.000.000 per kamp.

Alle udøverne - både dem vi fulgte i første og anden del af vores feltarbejde - trænede typisk en til to gange om dagen, fem til seks gange om ugen. MMA træningen foregik oftest i forhold til en specifik kampsportsgren, som BJJ eller kickboksning. Det var overraskende for os, at det 


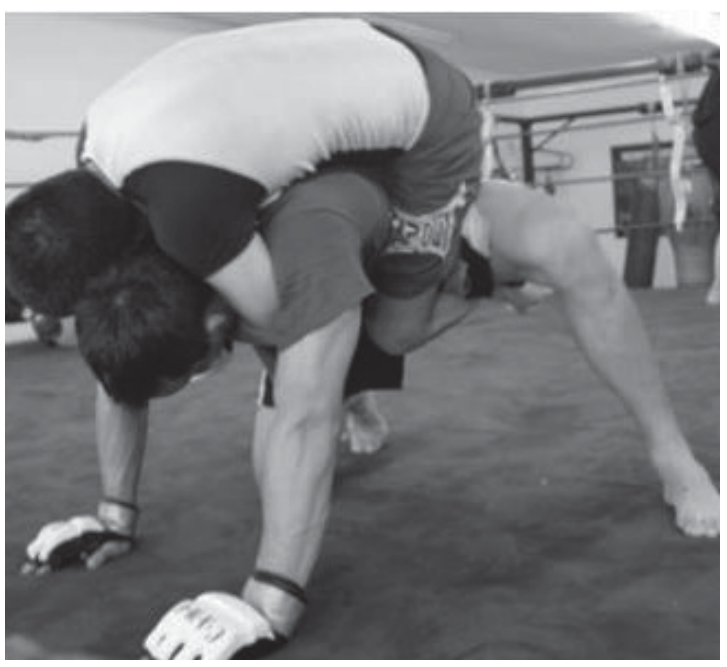

MMA sparring. Foto: Mariam Rosenwanger.

kun var i en mindre del af den samlede træning, at udøverne trænede med en aktiv kombination af de forskellige kampformer, sådan som kampteknikkerne skal mikses og anvendes i kampsituationen. Sparringen foregår grundlæggende i to former. I MMA sparringen bærer udøverne MMA udstyr, så hænderne er frie til at udøverne kan arbejde med de greb, låse og kast, der hører til i træningen af grappling. Der er således ikke nær den samme beskyttelse i handsken som i boksning, og derfor slår udøverne ikke igennem til partnerens hoved.

Den anden form for sparring foregår med fuldt udstyr, og her er der fokus på diverse slag og spark, da udstyret i sagens natur gør det umuligt at arbejde med grappling. I denne form for sparring slår og sparker udøverne hårdere både til krop og ansigt. Men som sociologen Wacquant også har beskrevet i forhold til sparringssituationen i boksning (2004, s. 87-91), er det en del af det gensidige engagement for prak- sisfællesskabet i denne kampform, at udøverne kan regulere og kontrollere den power de slår med. MMA udøverne beskriver selv, at de slår med omkring $80 \%$ af deres maksimale slagkraft. Sparringen handler i den forstand ikke kun om at øve teknik i kamplignede sammenhæng, men udgør en socialiseret måde at indgå i udøvernes praksisfællesskab på.

Med Wengers begreber (2008, s.89-90, 93-95, 100-101), er sparringen betinget af et gensidigt engagement og repertoire af handlemuligheder, der inkluderer at udøverne på en gang både slås og passer på hinanden - giver sig fuldt ud og udøver selvkontrol i forhold til partneren. Det var overraskende i feltarbejdet, at opdage hvilken afslappet stemning, der prægede træningen dvs. MMA's 'backstage' situationer Træningssituationen er dermed også fuldstændig anderledes end kampsituationen - eller det der repræsenterer MMA 'frontstage'.

Wacquant har fremhævet, hvorledes man skal være opmærksom på at selve sparringsseancerne, også fungerer som træningssekvenser, hvor udøvernes fysiske og mentale grænser overskrides (2004, s.88-91). Der sker en fortsat hærdning i forhold til at kunne modstå slag og smerte. Ifølge Massey et al. (2013) er der i MMA sparringerne tale om en nødvendig 'nedbrydning', der både forbereder udøverne på, hvad de kan forvente i kampen og samtidig danner grundlaget for, at udøverne kan blive endnu stærkere (Massey et al., 2013, s. 18). Green (2011) peger på, hvorledes smerten i MMA sammenhænge også kan spille en rolle $\mathrm{i}$ forhold til at opbygge og fastholde MMA udøverne. Med denne form for træning oplever udøverne, ifølge Green, en vis form for 'suverænitet', som også opleves som en frihed, der rækker ud over normative krav og forventninger. Green fremhæver, at udøverne i den fælles proces, hvor de indledningsvis påfø- 
rer hinanden smerte og bagefter kommer sig $\mathrm{i}$ fællesskab, opbygger relationer, der kan karakteriseres som familiære. I lighed med Greens beskrivelser var det gennemgående karakteristika for de MMA miljøer, der indgik i feltarbejdet, at udøverne på forskellig vis indikerede, at de 'føler sig i live' gennem denne udveksling mellem smerte og restitution.

Slag mod hovedet udgør en speciel kategori af hærdning. Flere af MMA udøverne fremhæver, at de i kampen ikke mærker disse slag på grund af adrenalinen. Omvendt er netop slag mod hovedet noget, der på forskellig vis minimeres eller helt undgås under træning - specielt under MMA sparringen. En kvindelig udøver fortæller:

A: "I definitely don't like getting punched in the face. That's like terrible... I don't like it in practice, because you don't have the adrenaline going. I used to get so frustrated, it would piss me off, because I didn't know how to do it and then I had guys punching me in the face, and I was like, this is all wrong, this is not right..."

MMA udøvernes træning er funderet i en stor tillid til, at deres sparringspartner på en gang både giver dem fuld udfordring, men også for-

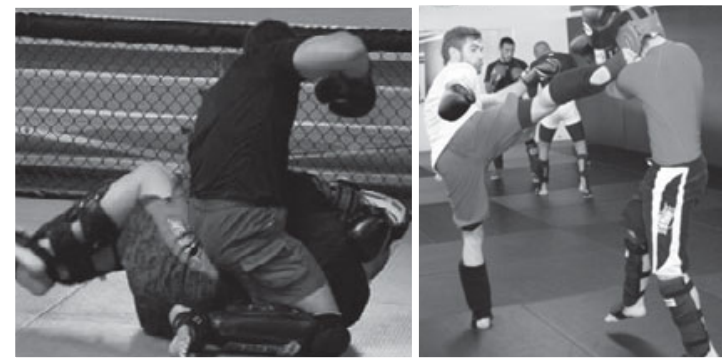

Fuldt udstyr sparring. Foto: Mariam Rosenwanger. mår at kontrollere den power, der lægges i slag og spark. Omvendt indikerer dette også, hvorledes MMA kampen i sig selv er en ekstrem situation, idet de færdigheder, som udøverne er fuldstændig afhængige af, når de står i buret, ikke kan trænes fuldt ud til dagligt. Sagt på anden vis, MMA udøverens kunnen trænes med backstage reglernes begrænsninger og afprøves først for alvor, når han eller hun står i buret.

\section{TRAENINGSFALLESSKABET OG PRIVATSFAREN}

MMA er for udøverne en livsstil, der består af meget aktive og bevidste valg fra udøvernes side, både i forhold til, hvordan de indgår i det praksisfællesskab, der kendetegner træningen, og i forhold til den måde de forholder sig til og indretter deres privatsfare. Der er forskel på udøvernes praksisfællesskaber, afhængig af det niveau de kæmper på. MMA udøverne der indgik i første del af feltstudiet, tilbragte væsentlig mere tid sammen udenfor MMA træningen - eksempelvis til fødselsdage og housewarmings.

Disse udøvere beskriver, at de ikke blot har et praksisfællesskab, der inkluderer et fælles repertoire af handlemuligheder forbundet med træning, men at de har et andet fællesskab, hvor de er forbundet gennem emotionelle forbindelser. I den forstand ekstenderer praksisfællesskabet og udøvernes relationer rækker ud over det repertoire af handlemuligheder, der er etableret i direkte forbindelse med for MMA træningen.

Som allerede beskrevet i forbindelse med sparringen, er den fælles virksomhed i træningen i høj grad båret af et gensidigt engagement. Udøverne beskriver eksempelvis:

B: "... [MMA] is more like a family brotherhood... your team helps you for free, but 
when it's their turn, you are there for them, so it's a give and take thing"

Y: "I'm only here to get better and help the other guys to get better. I never want to see anyone get hurt. I never wanna hurt anyone. Especially not these guys I know in the gym. You are not here to win a fight with your teammates"

Massey et al. (2013) fremhæver, at dette MMA træningsfællesskab har en positiv indflydelse på udøvernes fremtid. De går endda så langt som til at hævde, at sammenlignet med ikke-kampsportsudøvere er MMA udøverne 'mere oprigtige' $i$ forhold til at støtte og vise omsorg for hinanden.

For eliteudøverne inden for MMA, har praksisfællesskabet i perioderne op til kamp en langt mere perifer betydning for udøverens træningspraksis. Eller rettere det praksisfællesskab udøveren er en del af skifter karakter, idet træningen i langt højere grad bliver et projekt med fokus på et individs præstation. Den fælles virksomhed er i denne sammenhæng alene centreret om udøveren og det repertoire, der er gældende, ændres tilsvarende til primært at være rettet i forhold til optimering af netop én udøver. I stedet for at indgå i et træningsfællesskab, hvor alle må hjælpe alle på træningslejren, så ansætter og sammensætter den enkelte udøver et velfungerende, professionelt team, bestående af trænere, manager, samt sparringspartnere, til at støtte op om og optimere sin personlige træning. Som en af eliteudøverne forklarer:

"when you get to the high level, like my girlfriend is fighting for the world title, we're bringing in sparring partners to pay because it's hard for someone coming in to wanna get beat up by her...".
Dette praksisfællesskab har én fælles virksomhed, nemlig at målrette og forbedre udøverens færdigheder, således de matcher én specifik modstanders færdigheder.

På forskellige vis fremhæver MMA udøverne, at det er helt nødvendigt, at de personer, der hører til deres privatsfære både accepterer deres livsstil og er der ubetinget for dem. Privatsfæren bliver igen og igen fremhævet som 'det', der skal udgøre en stabil platform for deres fortsatte træning og involvering i kampe.

B: “... fighting is not an easy job, so it's really nice to know that if you don't win, you'll have all the people to fall back on and that helps me to be strong as a fighter"

Ordet 'positivitet' går igen for de fleste udøveres beskrivelse af fællesskabet og privatsfærens betydning. Som en elite MMA udøver udtaler:

A: "I try to surround myself with a lot of positive people around me, because I need positive energy, you know when I'm training. One of my coaches said to me that, you know, energy develops from basically positivity... The more happy I can feel, the more energy"

De nære relationer i privatsfæren skal være der for udøverne, når de har behov for det, mens de selv kun kan være der for privatsfæren, når det passer ind for dem i forhold til MMA kampe og træning. Det er ikke kun udøvernes praksisfællesskab, men også deres privatsfære, der er sammensat på selekteret vis og fordrer et fuldstændigt engagement i forhold til deres MMA livsstil.

Ifølge Wengers beskrivelser er det netop via praksisfællesskaberne, at deltagerne udvikler deres (sportslige) identitet (2008, s.89-90). Der er ingen tvivl om, at træningsteamet er et grun- 
delement for MMA udøverens forståelse af sig selv som MMA udøver. Samtidig er det dog bemærkelsesværdigt, at MMA udøverne ikke nævner dette praksisfællesskab, når de taler om den støtte de har brug for op til og efter kampene. I den sammenhæng er det primært privatsfæren, der har betydning for dem.

Den livsstil og alle de ressourcer, som MMA udøverne lægger i deres træning, forberedelse og kampe kan, som vi indikerede i indledningen, på mange måder sammenlignes med, hvorledes eliteatleter tilrettelægger hele deres liv i forhold til den nødvendige træning. Men MMA udøverne, der træner i forhold til amerikanske betingelser og med økonomiske perspektiver, der hører de professionelle til, manøvrerer i sammenhænge, der er særdeles anderledes end de sammenhænge og værdiforståelser, der ligger til grund for de forhold, der kendetegner nordiske eliteidrætsudøvere - som eksempelvis præsenteret ved den økologiske model (Henriksen, 2011). Set fra en nordisk kontekst betragtes det som et potentielt problem, hvis idrætstalenterne fravælger uddannelse og nedtoner eller eliminerer handlekontekster, der bidrager til udøverens identitet på anden vis end sporten (Ibid., s.174, 176, 179). Et godt elitesportsmiljø er i den sammenhæng kendetegnet ved god kommunikation mellem skolen, klubben, familien og vennerne. Der bidrages til et fælles miljø som støtter op om udannelse og giver trygge rammer. Det forventes at atleterne på den vis kan jonglere mellem eliteidræt og uddannelse på samme tid (Ibid., s. 96, 101-102, 119, 166, 179).

Som sagt udgør MMA udøvernes liv en del af den amerikanske kultur og udfolder sig dermed i forhold til helt andre betingelser og muligheder for uddannelse. Dette har selvfølgelig betydning i forhold til, at udøverne fra meget tid- lige tidspunkter i deres træning går 'all in' i forhold til at være MMA udøver, og eksempelvis helt bevidst fravælger en påbegyndt uddannelse. Henriksen definerer talent og eliteidrætsmiljøer som mindre velfungerende, hvis atleternes omgivelser, såsom klubben, skolen, familien og vennerne tvinger atleten til at vælge mellem sin sportslige, sociale og personlige identitet. Det er værd at bemærke, at for de amerikanske MMA udøverne er dette valg ikke blot nødvendigt, men ofte også en aktiv del af den fortælling, de skaber omkring deres eget virke.

A: "we took all the money that we had which was $\$ 2400$ and... had to apply for food assistance and things like that to train full time and not have to work a job, so that's what we did, and we did that for two years and we would barely making a $\$ 1000$ a fight. I would fight and then we would have a little bit of money and then we almost ran out of them and then he [boyfriend] would fight, and we were like "oh shoot, we're almost out of money and then I would fight and we were just scraping by. But it was good, it was definitely character building and we did that for a couple of years and then [big organization] signed me and he was fighting for [big organization] and went to the WEC and then we were starting to kind of making enough to afford normal living situation..."

På tværs af forskelle i kultur og samfundsforhold, og med de amerikanske udøvere som forbilleder vil danske udøvere ikke blot relatere sig til træningsmåder, men også til de meget anderledes fortællinger om, hvad der skal til for at gøre sig gældende indenfor eliten - i MMA. Forventeligt vil danske udøvere implementere dele 
af denne fortælling i forhold til deres egen selvforståelse og identitet som MMAudøver.

\section{VAETTAB - ET REPERTOIRE AF HANDLE- MULIGHEDER?}

Alle MMA udøvere kæmper i en af ni vægtklasser. Formålet med vægtklasser er at skabe en fair og sikker kamp og minimere risikoen for skader (Jetton et al., 2013).

Udøverne benytter sig af dicet og dehydrering for at komme i kampvægt (Harries et al, 1998, s.115). Diæten finder sted de første syv uger af træningslejren op til kamp. Udøverne taber sig i denne periode individuelt mellem $2-12 \mathrm{~kg}$ fra deres normalvægt, som oftest ligger en til to vægtklasser over deres kampvægt. Diætperioden kræver stor selvkontrol for at styre mængden og typen af mad, der må indtages, sådan at de samtidig får energi til at kunne præstere til træningen.

A: “...I try to put better food in my body, so I can get better results, because I have to be competitive in practice... Everything else becomes backburner basically. MMA is my no. 1 focus and I try not to break focus on that..."

Udøverne taler dog samtidigt meget om, hvor meget de elsker mad. Der er ikke noget værre end, at de ikke kan tillade sig at indtage store mængder af kulhydratrige og fedtrige produkter.

Dehydreringen, finder sted en til syv dage op til indvejningen, og i den periode taber udøverne 2-11 kg. De hyppigst anvendte dehydreringsmetoder er waterloading ${ }^{6}$, saltbad, sauna, eller let motion på løbebånd med sveddragt på. På trods af at udøverne har dehydreret sig utallige gange før, fylder denne proces meget i udøver- nes beskrivelse af deres forberedelse. Nogle ud$\emptyset$ vere betoner, at dehydreringen er hårdere end kampen og at de lider så meget, 'at det føles som at dø’. Vægttabsprocessen er kampen før kampen og den ultimative test af deres selv-kontrol.

C: "honestly, cutting weight and losing all those pounds in the camp and the final weight cut in the end, is probably the hardest thing I've ever done in my entire life. The weight cut is much harder than the fight"

Der er ikke restriktioner for hvor meget vægt udøverne maksimalt må dehydrere sig (Jetton et al, 2013), og der har været flere eksempler på, at ud$\emptyset$ vere har urineret blod, skadet deres nyrer eller er døde i forbindelse med dehydreringsfasen. ${ }^{7}$

Efter indvejningen er ingen af MMA udøverne klar til at træde ind i buret og kæmpe. De har brug for de 24 timer, der er mellem indvejningen og kampen til at genopfylde væskedepoterne via intravenøs behandling (IV) (Jetton et al, 2013). Udøverne ser IV som en form for sikkerhedsnet og forholdsregel - og en selvfølge, da de fleste i sporten benytter sig af det.

MMA udøverne er i forvejen til det ekstreme: den ekstreme kampform og det ekstreme livsvalg. At vægttabsperioden også handler om at gå til kanten og helst lidt længere kan vel næppe overraske, om end denne kamp og de helbredsmæssige risici, der er på spil, ikke er synlige, når publikum ser de to udøvere brydes og slå hinanden til blods i buret.

Det er væsentligt at forstå, at vægttabsprocesserne også udgør en stor del af MMA udøvernes fælles repertoire af handlemuligheder. Når formanden for Canadian Medical Association opfordrer til forbud mod MMA grundet de fysiske skader (CMA, 2013), så skal det tilføjes, at 
sundhedsmæssige såvel som etiske overvejelser ikke kan reduceres til diskussioner om, hvad der foregår i kampen. I og med at MMA netop udfoldes efter indvejningsregler, der giver relativt 'friere' rammer for at presse kroppen til det alleryderste $i$ forbindelse med dehydreringen, så er det mindst lige så væsentligt at få et større fokus på de implicitte koder og regler, der udfoldes 'backstage' i forbindelse med vægttabet, og som dermed er med til at definere MMA udøvernes praksis. ${ }^{8}$

\section{KONKLUDERENDE}

Z: “...let's say the part of you like the beast, you know there's no way that you can express that in society. You know, if you do that in society, you'll go to jail. But some people have that side of their personality, so this [MMA] is a way to channel that and sometimes people deal with their frustrations in ways that aren't positive. You know, but being a fighter is a way to channel all your negative energy and all your pain and everything you go through, into something you can turn positive. You know, there's a place, there's an outlet for you to express that side of yourself, that not everybody has"

Som det fremgår af citatet, betoner udøverne, at MMA giver mulighed for at følge sine dyriske instinkter og plads til at kanalisere frustrationer ud på en fysisk måde. Samtidig har vi netop vist $i$ analysen af deres daglige træning og kampforberedelser, at deres praksis på flere måder er præget af kontrol af disse 'kræfter'. Praksisfællesskabet er defineret ved en socialisering af, hvorledes træningen skal foregå - ikke mindst, hvordan MMA udøverne forventes at passe på hinanden $\mathrm{i}$ de forskellige sparringssituationer. Ligeledes er MMA udøvernes måde at organisere både deres privatliv og livssituation præget af valg, der kræver disciplin og investering af vilje. Sagt på anden vis, så er 'bæstet' - det dyriske - som er forbundet med iscenesættelsen af kampene og udøvernes selvforståelse som MMA udøver, betinget af at de kan klare en træningsindsats, der kan sammenlignes med eliteidrætsudøvernes. Men til forskel fra for eksempel det nordiske ideal om at sørge for, at eliteidrætsudøverne også indgår i andre handlekontekster end de, der har med deres sport at gøre, er MMA udøvernes måde at organisere deres liv på, karakteriseret ved et totalt engagement. For at vare MMA udøver må alt handle om MMA.

Det 'outlet' eller afløb, der henvises til i citatet, hører til den fortælling, der sammen med iscenesættelsen af kampen i buret, er væsentlige for den kollektive repræsentation, der er forbundet med 'MMA's frontstage.' Træningsfællesskabet - backstage - er dog kendetegnet ved særdeles stærke, næsten familiære relationer udøverne i mellem. I korthed: den vildskab, der slippes løs i buret næres af selvkontrol, fysisk hærdning og stærke relationer.

En stor tak til udøverne og MMA klubberne: Alliance Training Center, Black House MMA, Glendale Fighting Club, Gracie Barra Burbank, Hayastan MMA Academy, Reign Training Center, Syndicate MMA, Systems Training Center og Xtreme Couture $M M A$. Feltarbejdet havde ikke været muligt uden deres hjælp og velvilje.

\section{REFERENCELISTE}

Brinkmann, S. \& Tanggaard, L. (red.) (2010) Kvalitative Metoder. 1. udgave, 1.oplag, Hans Reitzels Forlag.

Giddens, A. (1990) The Consequences of Modernity. Stanford, California: Stanford University Press. 
Green, K. (2011) It hurts so it is real: sensing the seduction of mixed martial arts. Social \& Cultural Geography, 12(4), 377-396.

Hammersley, M. \& Atkinson, P. (2007) Ethnography, Principles in Practice. $3^{\text {rd }}$ edition, Routledge.

Harries, M., \& Williams, C. et al. (red.) (1998) Oxford textbook of sports medicine. 2.udgave. Toronto: Oxford University Press.

Henriksen, K. (2011) Talentudviklingsmiljøer $i$ verdensklasse. 1.udgave, 1.oplag. Dansk Psykologisk Forlag.

Henriksen, K. (2010) The Ecology of Talent Development in Sport. PhD Thesis form Institute of Sports Science and Clinical Biomechanics, Faculty of Health Sciences, University of Southern Denmark.

Jacobsen, M. H.; Schiermer, B. (red.) (2013): Faenomenologi - Teorier og metoder. 1.udgave, 1. oplag. Hans Reitzels Forlag.

Jetton, A. M., Lawrence, M. M., Meucci, M., Haines, T. L., Collier, S. R., Morris D. M. \& Utter, A. C. (2013) Dehydration and acute weight gain in mixed martial arts fighters before competition. Journal of strength and conditioning research, 27(5), 1322-1326.

Larsen, C. H. (2013) "Made in Denmark" - Ecological perspectives on applied sport psychology and talent development in Danish professional football. PhD Thesis form Institute of Sports Science and Clinical Biomechanics, Faculty of Health Sciences, University of Southern Denmark.
Massey, W. V., Meyer, B. B., \& Naylor A. H. (2013) Toward a grounded theory of self-regulation in mixed martial arts. Psychology of Sport and Exercise, 14, 12-20.

Rooney, M. (2008) Training for Worriers. 1.udgave, Collins.

Spencer, D. C. (2009) Habit(us), Body Techniques and Body Callusing: an Ethnography of Mixed Martial Arts. Body \& Society, 15(4), 119-143.

Wacquant, L. (2006) Body and Soul. Oxford University Press.

Wenger, E. (2008) Praksisfallesskaber. 1.udgave, 3.oplag. Hans Reitzels Forlag.

Woodward, T. W. (2009) A Review of the Effects of Martial Arts Practice on Health. Wisconsin Medical Journal, 108(1), 40-43.

\section{HJEMMESIDER OG RAPPORTER}

CMA (2013) Reports to General Council 2013. Hentet 7.juni 2015, fra https://www.cma.ca/ Assets/assets-library/document/en/aboutus/2013-05_Board_Stewardship-e. pdf\#search=Mixed \%20martial\%20arts

Cruz, G. (2013) MMA fighter dies moments before Shooto's weight-ins in Brazil. Hentet 6.juni 2015, fra http://www.mmafighting. com/2013/9/26/4775208/mma-fighter-dies-moments-before-shootos-weigh-ins-in-brazil

Cruz, G. (2013) Shooto Brazil 43 canceled after Leandro 'Feijao' Souza's death. Hentet 6.juni 2015, fra http://www.mmafighting. com/2013/9/27/4776750/shooto-brazil-43-canceled-after-leandro-feijao-souzas-death 


\section{NOTER}

1 Kampen udkæmpes i et ottekantet bur, Octagon, som er et nødvendigt sikkerhedstiltag for at udøverne ikke falder ud af kampområdet.

2 Se eksempelvis http://ekstrabladet.dk/sport/taesk/ article4713197.ece

3 Vi har udført kvantitativ opgørelse af kvalitativt relaterede data, for at finde karakteristika hos alle $37 \mathrm{MMA}$ ud øvere. Derefter transskriberede vi fem interviews, á 25 min hver, der rammer bredt $i$ forhold til alle udøvernes udtalelser.

412 transskriberede interviews, der varede i gennemsnittet 40 minutter

5 Temaerne var: 1) Identitet 2) fællesskaber og privatsfære 3) fysiske og kropslige udfordringer 4) overlevelse i sporten.
6 3-4 dage før indvejningen, undlades alt salt i mad og drikke, og samtidig indtages en stor mængde vand.

7 En udøver tog eksempelvis imod en kamp med 5 dags varsel, da der var mulighed for en indtjening og for at fremme karrieren. Han endte med at urinere blod og fik skadet sine nyrer efter at have tabt næsten $11 \mathrm{~kg}$ på 5 dage. Et andet eksempel fra 2013: I forsøget på at tabe $5 \mathrm{~kg}$ i løbet af det sidste døgn op til indvejningen faldt en MMA udøver om i saunaen og døde kort tid efter af et slagtilfælde (Cruz, 2013a; Cruz, 2013b).

8 Der er i skrivende stund ved at blive indført et forbud mod IV på mere end $6 \mathrm{~mL} / \mathrm{t}$. i en prøveperiode på 3 måneder fra 1.okt.2015. 